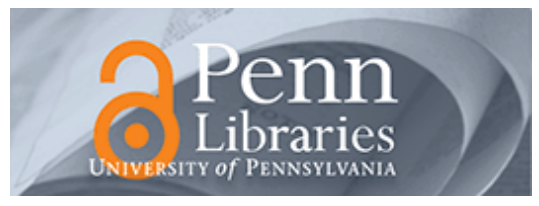

University of Pennsylvania

ScholarlyCommons

Accounting Papers

Wharton Faculty Research

$5-2006$

\title{
Discussion of The Role of Accruals in Asymmetrically Timely Gain and Loss Recognition
}

Wayne R. Guay

University of Pennsylvania

Follow this and additional works at: https://repository.upenn.edu/accounting_papers

Part of the Accounting Commons

\section{Recommended Citation}

Guay, W. R. (2006). Discussion of The Role of Accruals in Asymmetrically Timely Gain and Loss

Recognition. Journal of Accounting Research, 44 (2), 243-255. http://dx.doi.org/10.1111/

j.1475-679X.2006.00199.x

This paper is posted at ScholarlyCommons. https://repository.upenn.edu/accounting_papers/58

For more information, please contact repository@pobox.upenn.edu. 


\title{
Discussion of The Role of Accruals in Asymmetrically Timely Gain and Loss Recognition
}

\author{
Abstract \\ Ball and Shivakumar (2005) augment existing models of expected accruals to incorporate conditional \\ conservatism. They document a robust asymmetry in the relation between accruals and economic losses \\ and gains, and demonstrate that accruals models that incorporate this asymmetry have increased \\ explanatory power. This discussion of Ball and Shivakumar (2005) makes five main points: 1) \\ incorporating asymmetry in gain and loss recognition is an important contribution to empirical models of \\ expected accruals; 2 ) the economic underpinnings of asymmetry in loss and gain recognition remain \\ open to considerable debate; 3 ) the extent to which accruals recognize gains in a timely manner remains \\ an interesting but unanswered question; 4) non-working capital accruals are important to both the \\ earnings process and accounting conservatism, yet modeling of nonworking capital accruals has \\ received little attention in the literature; and 5) incorporating asymmetry into the accruals process has \\ important implications for estimating discretionary accruals and for future research in this area. \\ Disciplines \\ Accounting
}




\title{
Discussion of Ball and Shivakumar (2005): The role of accruals in asymmetrically timely gain and loss recognition
}

\author{
Wayne Guay ${ }^{1}$ \\ The Wharton School \\ University of Pennsylvania \\ 1300 Steinberg Hall-Dietrich Hall \\ Email: guay@wharton.upenn.edu \\ Phone: (215) 898-7775
}

\begin{abstract}
Ball and Shivakumar (2005) augment existing models of expected accruals to incorporate conditional conservatism. They document a robust asymmetry in the relation between accruals and economic losses and gains, and demonstrate that accruals models that incorporate this asymmetry have increased explanatory power.

This discussion of Ball and Shivakumar (2005) makes five main points: 1) incorporating asymmetry in gain and loss recognition is an important contribution to empirical models of expected accruals; 2) the economic underpinnings of asymmetry in loss and gain recognition remain open to considerable debate; 3 ) the extent to which accruals recognize gains in a timely manner remains an interesting but unanswered question; 4) non-working capital accruals are important to both the earnings process and accounting conservatism, yet modeling of nonworking capital accruals has received little attention in the literature; and 5) incorporating asymmetry into the accruals process has important implications for estimating discretionary accruals and for future research in this area.
\end{abstract}

December 14, 2005

\footnotetext{
${ }^{1}$ I appreciate helpful comments from Philip Berger and John Core, and acknowledge the support of The Wharton School.
} 


\section{Introduction}

The accrual process is central to financial accounting. Accruals adjust cash flows to reported earnings and form the building blocks for the balance sheet. Given the importance of accruals to financial accounting, it is surprising how sparse the modeling of the overall accrual process has been within the literature. Until recently, the "state of the art" empirical approach modeled total accruals as a function of the change in sales and PP\&E (Jones, 1991). Recently, working capital accruals have been more formally modeled as a function of firms' selling activity and past, present, and future operating cash flows (e.g., Dechow, Kothari and Watts, 1998; Dechow and Dichev, 2002).

Ball and Shivakumar (2005) incorporate conditional conservatism, an important feature of the earnings process, into existing accruals models. Specifically, they recognize that accruals are expected to be an asymmetric function of firm performance in which economic losses are captured by the accruals process in a more timely manner than gains. Their evidence documents a robust asymmetry in the relation between accruals and economic losses and gains, and demonstrates that accruals models that incorporate this asymmetry have increased explanatory power. The authors' innovation advances research on modeling the accruals process and is sure to play an important role in accounting research on both nondiscretionary and discretionary components of accruals.

This discussion begins in Section 2 by reviewing existing models of expected accruals. Section 3 illustrates the role of accruals in recognizing gains and losses and argues that the extent to which accruals recognize gains in a timely manner remains an interesting but unanswered question. In Section 4, I discuss the authors' main tests and contributions to our understanding of the asymmetric recognition of losses and gains. I also argue that the economic underpinnings of 
asymmetry in loss and gain recognition remain open to considerable debate. Section 5 briefly ties the authors' work into extant research on estimating discretionary accruals and provides avenues for future research. Section 6 offers concluding remarks.

\section{Models of expected accruals}

The accruals model developed by Jones (1991), one of three models examined by Ball and Shivakumar, is an early attempt to empirically describe the accrual process. Somewhat surprisingly, this early model is still widely used by researchers to estimate expected accruals and deviations from expected accruals. The Jones model relies on the fundamental notions that working capital accruals, such as receivables and inventory, are expected to increase with sales, and that long-term accruals, such as depreciation, are expected to increase with investments in plant, property and equipment. Because growth in receivables and inventory increases earnings relative to operating cash flows, and depreciation expense decreases earnings relative to cash flows, $\alpha_{1}$ is predicted to be positive, and $\alpha_{2}$ is predicted to be negative in the following specification:

Jones model: $A C C_{t}=\alpha_{0}+\alpha_{1} \Delta R E V_{t}+\alpha_{2} G P P E_{t}+\varepsilon_{t}$

where ACC is total accruals (i.e., earnings minus operating cash flows), $\triangle \mathrm{REV}$ is the one-period change in revenues, and GPPE is the gross value of plant, property, and equipment.

The other two models examined by Ball and Shivakumar, one relying on work by Dechow, Kothari, and Watts (DKW, 1998) and the other developed by Dechow and Dichev (DD, 2002), are based on the fundamental idea that working capital accruals improve the 
informativeness of earnings by smoothing out transitory fluctuations in working capital cash flows, such as inventory and accounts receivable. For example, consider a buildup in inventory in the previous period that is sold on account in the current period and subsequently collected in cash the next period. Consequently, operating cash flow is negative last period, zero in the current period when the earnings process is actually completed, and positive next period. Such transitory fluctuations make operating cash flows a less informative measure of firm performance than earnings (e.g., see Dechow, 1994). Ball and Shivakumar refer to this as the "noise reduction" role of accruals. Thus, these models emphasize the relation between accruals and past, current, and future operating cash flows as follows:

$$
\begin{aligned}
& \text { Cash flow (CF) model: } \quad A C C_{t}=\alpha_{0}+\alpha_{l} C F_{t}+\varepsilon_{t} \\
& \text { Dechow-Dichev (DD) model: } A C C_{t}=\alpha_{0}+\alpha_{l} C F_{t}+\alpha_{2} C F_{t-1}+\alpha_{3} C F_{t+1}+\varepsilon_{t}
\end{aligned}
$$

where $\mathrm{ACC}$ is total accruals, and $\mathrm{CF}_{\mathrm{t}-1}, \mathrm{CF}_{\mathrm{t}}$, and $\mathrm{CF}_{\mathrm{t}+1}$ are one-period lagged, current, and oneperiod future operating cash flows, respectively. Note that although DKW and DD explicitly model only working capital accruals, Ball and Shivakumar (and DKW) empirically examine total accruals as the dependent variable in Eqs. (2) and (3). I return to this issue below.

All three models, Jones, CF, and DD, rely on a similar idea: accruals are expected to be a function of firms' real business activity, where real business activity is predominantly captured by increases or decreases in firm sales. The Jones model includes the change in sales directly in the model. The CF and DD models are both derived from the accruals process framework developed by DKW. DKW begin with a model that relates sales to accruals and derive contemporaneous and lead-lag relations between accruals and operating cash flow under the 
explicit assumption that accruals resolve timing and matching problems. DD extends DKW by recognizing that current period accruals that are not a function of prior period and future period cash flows may be of lower quality. The CF model is a special case of the DD model in that it uses only current period cash flow as a workhorse to capture business activity and therefore assumes that all accruals have the same relation with business activity.

As described in detail below, Ball and Shivakumar's main tests of conditional conservatism consist of adjustments to Eqs. (1), (2), and (3) using total accruals (i.e., including both short-term and long-term accruals) as the dependent variable. Of the three accruals models described above, only the Jones model attempts to explain variation in short- and long-term accruals. The Jones model explicitly models long-term accruals from depreciable assets, although it excludes other non-working capital accruals such as deferred taxes and restructuring charges. DKW and DD acknowledge that long-term accruals are associated with cash flows, and also potentially resolve timing and matching problems. Guay and Sidhu (2001) document empirically that long-term accruals in general, as well as individual components of long-term accruals such as depreciation and deferred tax, resolve timing and matching problems in cash flows in much the same way as short-term accruals. Further, they show that the cross-sectional variance of aggregate long-term accruals as well as individual components of long-term accruals are large, suggesting that an accruals model designed only to explain working capital accruals is likely to explain total accruals with substantial error. DKW and DD note that modeling longterm accruals is more difficult than working capital accruals because the relation between longterm accruals and cash flows occurs over a longer and more variable time period. Thus, the CF and DD accruals models in Eqs. (2) and (3) above have no explicit modeling of long-term accruals. 
It is useful to consider how well working capital accrual models are expected to perform in tests by Ball and Shivakumar, DKW, and many other empirical papers that examine total accruals, inclusive of both working capital and long-term accruals. Ball and Shivakumar provide some insight into this question in additional detail contained in the conference version of the paper that has been dropped in the published version. Specifically, they examine the explanatory power of the DD model when individual components of accruals are used as the dependent variable in the accruals regressions. The coefficients on the explanatory variables in the DD model are quite similar across regressions where individual working capital accruals (e.g., accounts receivable and inventory) are the dependent variables. However, when individual components of long-term accruals (e.g., depreciation) are the dependent variables, the coefficients are very different from those of regressions with short-term accruals as the dependent variables. This suggests that constraining all short-term accruals to have the same relation with the explanatory variables may not be a problem, but that constraining the coefficients across short-term and long-term accruals is likely to reduce the explanatory power of the models. Further, some of the more interesting accruals associated with asymmetry and conservatism, such as restructuring charges, goodwill impairments, and asset write-downs, are long-term accruals. The modeling of long-term accruals appears to be a topic for future research.

\section{Gains and loss recognition role of accruals}

Ball and Shivakumar argue that the accruals models described above can be improved by recognizing that in addition to resolving timing and matching problems in working capital cash flows, accruals also serve to recognize economic gains and losses in a timely manner. They refer to gains and losses as shocks to current period cash flows plus revisions in the expectation of 
firms' future cash flows. The authors provide intuitive examples of gains and losses in short-term accruals such as changes in the value of trading securities, inventory write-downs, and receivables revaluations. They also provide examples of gains and losses in long term accruals, such as restructuring charges, goodwill impairment charges, and asset impairment charges.

Considerable empirical evidence documents that the timely recognition of gain and loss accruals yields an earnings measure that improves upon cash flows as a measure of firm performance (e.g., Dechow, 1994; DKW, 1998). Watts (2003) makes the often overlooked point that the timely recognition of both gain and loss accruals increases the efficiency of the earnings measure for debt and compensation contracting:

Agency cost-reducing contracts include debt contracts between the firm and holders of the firm's debt, management compensation contracts, employment contracts, and costplus sales contracts. Contracting parties demand timely measures of performance and net asset values for compensation and debt contract purposes. Ceteris paribus, managerial performance measures in compensation contracts, such as earnings, are more effective when they are timely and reflect the effects of the managers' actions on firm value in the period in which the actions are taken. Timeliness avoids dysfunctional outcomes associated with managers' limited tenure with the firm, often referred to as the manager's limited horizon. For example, a manager may forgo positive net present value projects with near-term negative earnings because future earnings will reflect the benefits of the project after the manager has retired or left the firm (Watts, 2003a, pg. 211).

Many researchers emphasize the importance of timely recognition of losses in writing efficient debt, compensation, and other contracts over accounting earnings. However, timely recognition of gains should also generally result in more efficient contracts written over earnings. This point should not be surprising. The exclusion of timely gain accruals makes earnings a less informative measure of firm performance, and it is difficult to construct a contracting setting where less informative earnings make the contract more efficient. Thus, contracts written over earnings are 
expected to be more efficient when both loss and gain accruals are recognized in a timely manner (subject to cost considerations as described in Section 4). ${ }^{2}$

Ball and Shivakumar identify four proxies for economic gains and losses: (1) current period cash flows, (2) change in cash flows, (3) industry-adjusted cash flows, and (4) marketadjusted stock returns. They include these proxies as additional explanatory variables in Eqs. (1), (2) and (3) above. As described in Section 4, they also allow the coefficients on economic gains and losses to differ for gains as compared to losses. For example, in Eq. (1), when the change in cash flows is used as the proxy for economic gains and losses, the authors' regression is estimated as follows:

$$
A C C_{t}=\alpha_{0}+\alpha_{1} \Delta R E V_{t}+\alpha_{2} G P P E_{t}+\alpha_{3} \Delta C F_{t}+\alpha_{4} D \Delta C F_{t}+\alpha_{5} D \Delta C F^{*} \Delta C F_{t}+\varepsilon_{t}
$$

where $\Delta \mathrm{CF}_{\mathrm{t}}$ is the change in operating cash flow from period t-1 to $\mathrm{t}$, and $\mathrm{D} \Delta \mathrm{CF}_{\mathrm{t}}$ is a dummy variable equal to one when $\Delta \mathrm{CF}_{\mathrm{t}}$ is negative, and zero otherwise.

Before turning to the authors' main tests, which relate to predictions and inferences about the incremental timeliness of accruals in reflecting losses (i.e., $\alpha_{5}$ ), I discuss the frequently overlooked timeliness of gains. The authors do not explore the question of whether accruals recognize gains in a timely manner. Specifically, they make no predictions or inferences about the coefficient on the proxy for economic gains and losses that they estimate in their accruals regressions (e.g., $\alpha_{3}$ in Eq. (4) above).

The reason the authors do not draw inferences about the timeliness of gains appears to be two-fold. First, they note that the inference from their cash-flow-based proxies for economic

\footnotetext{
${ }^{2}$ See Guay and Verrecchia (2005) for a more detailed discussion of the role of timely recognition of both gains and losses in earnings.
} 
gains and losses is complicated by the correlation between these proxies and some of the independent variables in the accruals models. For example, there is a clear correlation between the cash-flow-based proxies for economic gains and losses and the lagged, current and future cash flows that DD include to capture the quality with which working capital accruals resolve matching problems. The authors' concern about the influence of these correlations appears valid. Although the coefficient on economic gains and losses, $\alpha_{3}$ in Eq. (4) above, is expected to be positive (i.e., accruals should increase with gains and decrease with losses), the authors find a significant negative coefficient in their Table 3, Panel B. This finding suggests that the coefficient on Ball and Shivakumar's proxy for economic gains and losses in this specification is dominated by the smoothing function of working capital accruals modeled by DKW, that is, by the negative predicted relation between cash flows and working capital accruals.

The second reason that the authors do not explore whether accruals reflect both timely gains and losses appears to be something of a lack of interest within the literature. As noted above, subject to cost considerations, timely recognition of both losses and gains is a desirable property of earnings and accruals that is expected to improve the efficiency of contracts. Although Ball and Shivakumar briefly list explanations for why financial reporting might exhibit timelier recognition of losses than gains, there is no apparent reason to believe that contracts demand only losses to be timely (in Section 4 below, I expand on this issue). However, while the timeliness of losses has been the focus of much recent study, the timeliness of gains has been largely ignored. As a result, our understanding of the timeliness of gains is lacking, and the general question of whether and when accruals recognize gains in a timely manner is left unanswered for future research. 


\section{Asymmetric recognition of gains and losses in accruals}

Ball and Shivakumar's main hypothesis is that accruals exhibit conditional conservatism in recognizing gains and losses, that is, accruals exhibit timelier recognition of economic losses than gains. Their tests explore whether accruals models that explicitly consider this asymmetry have greater explanatory power than models that do not.

Although a large volume of empirical literature beginning with Basu (1997) documents that accounting earnings do exhibit asymmetry with respect to gains and losses, there is considerable debate over the economic determinants of this asymmetry. ${ }^{3}$ One interpretation of the literature is that the demand for asymmetrically timely earnings can be explained by the following two part contracting-related hypothesis: 1) accrual accounting is a costly activity, and 2) contracting parties have a greater demand for timely loss recognition than timely gain recognition.

Both parts of the hypothesis are critically important. First, accrual accounting must be non-trivially costly. As noted above, earnings that incorporate only timely losses are less informationally efficient than earnings that incorporate both timely losses and gains. Therefore, if accrual accounting is not very costly, earnings that incorporate both timely losses and gains are expected to be preferred for contracting (as well as being preferred for valuation and other uses of accounting earnings).

Is accrual accounting actually costly? Although detailed discussion of the direct or indirect costs of accrual accounting is somewhat sparse in the conservatism literature, it certainly seems likely that the costs are non-trivial. Constructing expectations and changes in expectations about future cash flows related to assets and liabilities can be time-consuming and both capital

\footnotetext{
${ }^{3}$ For excellent summaries of the theory and empirical work on conservative accounting, see Ball (2001) and Watts (2003a and 2003b). Also, see Guay and Verrecchia (2005) for a more detailed discussion of related points on the demands for symmetric and asymmetric recognition of gains and losses in contracting.
} 
and labor intensive. Further, as noted by Watts (2003a), verifying such expectations can be costly, and there may also be greater litigation costs associated with forecasts of future cash flows that subsequently turn out to be incorrect.

The second part of the hypothesis is that the contracting-based demand for timely gains and losses is not symmetric. Note that the issue here is not whether shareholders, debtholders and managers would prefer to contract over earnings that incorporate only timely losses - it has already been noted above that they would generally prefer to contract over informationally efficient earnings that incorporate both timely losses and gains. Instead the issue is whether and why the benefits derived from information about losses are greater than the benefits derived from information about gains. Debt and compensation contracts are widely used in the literature to motivate the demand for asymmetric timeliness of gains and losses, and so I focus my discussion on these two settings.

Watts (2003a) and Ball and Shivakumar (2005a) argue that timely gain recognition is in less demand than timely loss recognition because managers will voluntarily disclose information about gains. However, because the financial accounting system explicitly excludes the timely recognition of many economic gains, it is not clear how such voluntary disclosures about gains are verified at low cost outside the accounting system. It is difficult to write contracts over voluntarily disclosed information. Therefore, it is not clear how debt and compensation contracts will be more efficient when they are written over a combination of audited financial earnings that incorporate timely losses and nonaudited voluntary disclosures about gains.

However, the arguments in the literature about voluntary disclosure of gains may not be critical to constructing an argument for why debt contracting would demand relatively more timely information about losses than gains. Debtholders' financial claims are more sensitive to 
bad news about profitability or the value of net assets than they are to good news. For example, holders of debt in a financially healthy firm are more likely to find significant bad news relevant to valuing their claims, and are less likely to find good news important in valuing their claims. As a result, if both timely gains and losses are costly to incorporate into earnings, debt contracting will create a demand for relatively more of the timely loss accruals (and contracting parties will be willing to wait until difficult-to-verify gains are realized, at which point they become easier to verify and are incorporated into earnings).

The demand in executive compensations contracts for asymmetric recognition of gains and losses is less obvious. Because accrual accounting and cash accounting result in the same total earnings over time (subject to clean surplus and other standard assumptions), preferences over accounting systems for compensation contracting are related to managerial horizon issues. A large literature documents the existence of both underinvestment and overinvestment by managers with short horizons. For example, as Ball and Shivakumar (2005a) note, if losses are not recognized in a timely manner in earnings, managers with short horizons may not discontinue poorly performing projects. There is a flip side however, as recognized in the quote by Watts (2003a) cited above. If gains are not recognized in a timely manner, managers with short horizons may forgo investing in positive NPV projects. ${ }^{4}$ Therefore, if we make the assumption that it is efficient to write compensation contracts over accounting earnings (as opposed to contracting over stock returns or other performance measures), it is not clear why or

\footnotetext{
${ }^{4}$ As an example of a setting where timely gain and loss information might be important, consider a recent study by Bushman, Piotroski, and Smith (2005), who examine in a global setting the speed with which managers increase or decrease investment flows in response to improved or deteriorating investment opportunities, respectively. The focus of the authors' analysis is whether managers decrease investment flows in response to deteriorating investment opportunities more quickly when accounting information about losses is more timely. However, the authors' descriptive statistics indicate that the speed with which managers increase investment flows in response to improved investment opportunities varies as much across countries as the speed with which managers decrease investment flows in response to deteriorating investment opportunities. This comparison suggests that providing incentives for managers to take positive NPV projects may well be equally as important as providing managers with incentives to shut down negative NPV problems.
} 
how a compensation contract would be more efficient by excluding timely information about economic gains.

It is also important to note that as long as the second part of the contracting-based hypothesis is valid (i.e., the existence of an asymmetric demand for gain and loss accruals), it is not necessary that gain and loss accruals have asymmetric costs. In other words, since net benefits equal gross benefits less costs, the net benefits of recognizing losses can be greater than that of gains even when the costs are the same. This is helpful because it is not always clear how much more costly gains are to verify and incorporate into earnings than losses. For example, the accounting rules dictating impairments of tangible and intangible assets require managers to estimate future cash flows that will be generated by the assets. Those estimates may yield lower or higher values for the assets, and it is unclear why verifying one outcome is more costly than the other. As another example, the lower-of-cost-or-market rule for inventories requires managers to make income-decreasing accruals when estimates of the value of inventory suggest a decline in value, but not an increase in value. It is not clear why estimates of increases in inventory value are more costly to verify than decreases in inventory value.

Regardless of the reasons behind asymmetry of gains and losses in earnings, it is empirically well-documented that earnings are indeed asymmetric in the recognition of gains and losses. Therefore, it is important to incorporate this empirical regularity into accruals models. To test the prediction that accruals models have greater explanatory power when this asymmetry is considered, Ball and Shivakumar construct a piecewise linear regression that allows the coefficient on proxies for economic gains and losses to vary across positive and negative values, as in Eq. (4) above. The incremental coefficient on losses, $\alpha_{5}$ in Eq. (4), is predicted to be positive. Across all three accruals models (Jones, CF, and DD), and for all proxies for economic 
gains and losses, accruals are shown to recognize economic losses in a more timely manner than gains. Further, the authors show that this result is robust to many empirical specifications.

Is the asymmetric recognition of economic gains and losses in accruals best modeled with a piecewise linear specification with a single 'kink'? It is difficult to say. Certainly, one could argue that multiple kinks could improve the specification because some accruals are explicitly designed to be a nonlinear function of gains and losses. For example, consider the two-part rules for long-lived asset impairments. First, firms must determine whether the undiscounted expected cash flows from the asset are less than the net book value of the asset. Conditional on this being the case, the asset impairment is based on the difference between the net book value of the asset and the discounted expected cash flows from the asset. If the undiscounted expected cash flows are greater than the net book value, no impairment is recognized. Thus, the impairment rules are designed to ignore small economic losses on long-lived assets (e.g., where expected cash flows decline, but not by too much), but to fully recognize the decline in value for large economic losses. It remains to be seen whether more complex piecewise linear or non-linear specifications of accruals will improve upon the Ball and Shivakumar specification. However, any such improvements to this model should be grounded in a well-specified theory of the appropriate functional form.

In summary, the Ball and Shivakumar findings are important and should be noncontroversial given existing literature on the asymmetry with which earnings recognize positive and negative news. Future research that models the accrual process will be better specified by incorporating this asymmetry.

\section{Unexpected accruals and discretionary accruals}


Within the accounting literature, the most commonly examined aspect of accrual expectation models is the residuals, or unexpected accruals. Numerous papers use estimates of unexpected accruals as proxies for accruals quality or the discretionary use of accruals. It is wellknown that the residuals from these models estimate discretionary accruals with considerable error (e.g., Dechow, Sloan and Sweeney, 1995; Guay, Kothari and Watts, 1996). There are two general types of error: 1) the residuals can contain nondiscretionary accruals, and 2) the estimates of nondiscretionary accruals (i.e., the predicted or fitted values from the models) can contain discretionary accruals. What are the implications of these errors and how does the Ball and Shivakumar approach help mitigate these problems?

First, let us consider the case where the residuals from accruals models contain nondiscretionary accruals. This is likely to be the case when firms experience performancedriven shocks to earnings that cause accruals to deviate from their normal relation with the independent variables in the accruals model. For example, the Jones model assumes that the accrual component of earnings is a constant proportion of changes in sales and PP\&E. When a firm builds up inventory in anticipation of future growth in sales, the Jones model considers this inventory activity to be a discretionary accrual. At best, this specification problem will cause measurement error that makes it difficult for researchers to document predicted relations between discretionary accruals and economic variables of interest. More problematic however, is the fact that the error in discretionary accruals is often correlated with firm performance, and in many settings, the researcher examines a stimulus for earnings management that is also correlated with firm performance. For example, consider the researcher who examines whether firms attempt to inflate stock price by managing earnings upward prior to accessing the capital markets. Firms raising capital generally have experienced positive growth and performance, and these firms will 
likely be found to have positive discretionary accruals simply because the Jones model fails to capture these shocks (regardless of whether there exists true earnings management caused by capital raising activities). In these cases, the researcher's tests will be biased toward finding earnings management (Dechow, Sloan, and Sweeney, 1995).

Ball and Shivakumar's approach recognizes that accruals in the presence of poor performance are expected to be asymmetric relative to accruals in the presence of good performance. As a result, their adjustment to the accruals models may aid researchers in mitigating performance-induced measurement error. To provide evidence on this point, it would be interesting to identify specific settings or samples of firms where the Ball and Shivakumar approach alters inferences about discretionary accrual behavior vis-à-vis inferences from existing accruals models.

A related development in the quest to purge performance-driven measurement error in discretionary accruals is put forward by Kothari, Leone, and Wasley (KLW, 2005). KLW suggest a matched-sample approach, which can be useful when the variable of interest is not well-modeled and the functional form between the variable of interest and the explanatory variables is not well understood. KLW choose return on assets as their matching variable under the assumption that a key component of the measurement error in discretionary accruals is the presence of nondiscretionary accruals that are correlated with firm performance. The benefit of such an approach is that discretionary accruals should be purged of a strong correlation with firm performance. The cost however is that the researcher must compute performance-matched discretionary accruals as the difference between two estimates of discretionary accruals (the treatment firm and the control firm) that are both measured with substantial error. Therefore, 
although the resulting discretionary accrual measure is expected to be less biased with respect to firm performance, it is also expected to contain greater noise.

It is possible that the Ball and Shivakumar approach and the KLW approach accomplish similar things. The former recognizes that the accruals process is correlated with firm performance as measured by proxies for economic losses, while the latter recognizes that the accruals process is correlated with firm performance as measured by return on assets. Ball and Shivakumar recognize that the accruals process is asymmetric in firm performance. Likewise, KLW's matched-sample approach implicitly allows for an asymmetric relation between accruals and firm performance. In fact, the KLW approach allows for not only asymmetry, but also for the possibility that the relation between accruals and firm performance is a more complicated functional form. Indeed, one of the motivations behind the KLW approach is that accruals models misclassify nondiscretionary accruals as discretionary for firms with extreme earnings performance. It would be interesting to know whether the Ball and Shivakumar and KLW approaches are each incrementally helpful in estimating discretionary accruals.

The second measurement error problem with discretionary accruals models is that estimates of non-discretionary accruals may contain discretionary accruals. As noted in KLW, if the motivation for discretionary accruals is related to the explanatory variables in the accruals models, the models will misclassify some discretionary accruals as nondiscretionary. For example, the Jones model includes change in sales as a proxy for growth-driven working capital accruals. Therefore, if firms that experience a decline in sales attempt to meet earnings targets via positive discretionary accruals, the residuals from the Jones model will not capture all of the discretionary accruals. This implies that if the question the researcher wants to answer is, "What is the magnitude of discretionary accruals being used by a given set of firms," models that 
control for firm performance will understate true discretionary accruals. On the other hand, if the motivation for discretionary accruals is not recent firm performance (or at least is not highly correlated with firm performance), such as discretionary accruals around grants of executive stock options, the residuals from the accruals should contain a substantial fraction of the discretionary accruals. Neither the Ball and Shivakumar approach nor the DLW approach appears to resolve this second measurement error problem.

\section{Conclusion}

Understanding the accrual process and developing good models that accurately capture the behavior of accruals is a key issue in a broad range of accounting research. Ball and Shivakumar (2005) incorporate conditional conservatism, the asymmetric timeliness with which accruals recognize economic losses, into the existing accruals models. The authors' findings are important and consistent with existing literature on the asymmetry with which earnings recognize positive and negative news, and should result in better specified models of the accrual process.

At the same time, the authors' analysis highlights several issues for future research. First, the modeling of when and to what extent accruals recognize economic gains is left as an unanswered question. The timely recognition of economic gains is expected to improve contracting efficiency, and even though loss recognition is more timely than gain recognition, it would be helpful to know more about the timeliness of gains and how it should be modeled. Ball and Shivakumar are not able to interpret their regression coefficients on economic gains due to econometric issues, and so leave this question for future research. Second, the modeling of working capital accruals has received the most attention in the literature and as a result working 
capital accruals are better understood than long-term accruals. More accurate models of longterm accruals will likely improve the overall modeling of the accrual process. Finally, Ball and Shivakumar's results suggest improvements that can be made to models of the discretionary accrual component of earnings. Recent work by Kothari, Leone, and Wasley (2005) argues that performance-matched discretionary accruals measures are necessary because accruals expectations models do not adequately control for the relation between accruals and firm performance. As models of expected accruals become more complete (e.g., by incorporating asymmetries in the recognition of economic gains and losses), performance matching may be less necessary or may require a performance-matching variable that is different from the return on assets measure advocated by Kothari et al. (2005). 


\section{References}

Ball, R., 2001, "Infrastructure requirements for an economically efficient system of public financial reporting and disclosure," Brookings-Wharton Papers on Financial Services, R. Litan and R. Herring (eds), Washington: Brookings Institution Press: 127-169.

Ball, R., and L. Shivakumar, 2005, "The role of accruals in asymmetrically timely gain and loss recognition," forthcoming in Journal of Accounting Research.

Ball, R., and L. Shivakumar, 2005a, "Earnings quality in U.K. private firms: comparative loss recognition timeliness," Journal of Accounting \& Economics 39, 83-128.

Basu, S., 1997, “The conservatism principle and the asymmetric timeliness of earnings," Journal of Accounting \& Economics 24, 3-37.

Bushman, R., Piotroski, J., and A. Smith, 2005, "Capital allocation and timely accounting recognition of economic losses: International evidence," Working paper, University of Chicago.

Dechow, P., 1994, "Accounting earnings and cash flows as measures of firm performance: The role of accounting accruals," Journal of Accounting \& Economics 18, 3-42.

Dechow, P. and I. Dichev, 2002, “The quality of accruals and earnings: The role of accrual estimation errors," The Accounting Review 77, 35-59.

Dechow, P., Kothari, S.P., and R. Watts, 1998. "The relation between earnings and cash flows," Journal of Accounting \& Economics 25, 131-214.

Dechow, P.M., Sloan, R.G., and A. P. Sweeney, 1995. "Detecting earnings management," The Accounting Review 70, 193-225.

Guay, W., Kothari, S.P., and R. Watts, 1996, “A Market-Based Evaluation of DiscretionaryAccruals Models,” Journal of Accounting Research 34, Supplement: 83-105.

Guay, W., and B. Sidhu, 2001, “The Usefulness of Long-Term Accruals,” Abacus 37: 110-131.

Guay, W., and R. Verrecchia, 2005, "Discussion of Bushman and Piotroski (2005) and theory of conservative accounting," Working paper, University of Pennsylvania.

Jones, J., 1991, “Earnings Management during import relief investigations,” Journal of Accounting Research 29, 193-228.

Kothari, S.P., Leone, A., and C. Wasley, 2005, "Performance matched discretionary accrual measures," Journal of Accounting and Economics 39 163-197.

Watts, R., 2003a, "Conservatism in accounting part i: Explanations and implications," Accounting Horizons 17 (3), 207-221. 
Watts, R., 2003b, "Conservatism in accounting part ii: Evidence and research opportunities," Accounting Horizons 17 (4), 287-301. 